\title{
Analgesic Activity of Phyllanthus lawii Extract in Swiss Albino Mice
}

\author{
Kodangala Subraya Chandrashekar*,, Santanu Saha ${ }^{2}$ and Prasanna Kodangala Subraya ${ }^{3}$
}

\begin{abstract}
${ }^{1}$ Department of Pharmacognosy, Manipal College of Pharmaceutical Sciences, Manipal University, Manipal-576104, India; ${ }^{2}$ Department of Pharmacognosy, Nitte Gulabhi Shetty Memorial Institute of Pharmaceutical Sciences, Deralakatte, Mangalore-574160, India; ${ }^{3}$ Department of Community Medicine, Father Muller Medical College, Mangalore575004
\end{abstract}

\begin{abstract}
The analgesic activity of the methanol extract of Phyllanthus lawii (MEPL) was investigated in Swiss albino mice with hot plate and acetic acid induced writhing models. The results suggested that MEPL possess potent analgesic activity. The MEPL produced a significant decrease in mice writhing induced by acetic acid suggesting peripheral analgesic activity and elevated mean basal reaction time in hot plate method suggesting central analgesic activity. The results are in agreement with its traditional use for pain treatment of $P$. lawii.
\end{abstract}

Keywords: Phyllanthus lawii, methanol extract, acetic acid induced, analgesic activity, swiss albino mice.

\section{INTRODUCTION}

Some species of Phyllanthus L. (Euphorbiaceae) are reported to be bitter, astringent, stomachic, diuretic, febrifuge, and antiseptic and have been used as hepatoprotective agents in Ayurvedic medicine [1]. The chemical and pharmacological properties and clinical studies of some Phyllanthus species have been summarized in a review article [2]. Of the Phyllanthus market samples, about $76 \%$ contains $P$. amarus Schum. \& Thonn. and the remaining percentage is shared by several other species [3]. Phyllanthus lawii Grah. is a glabrous shrub usually growing along the bank of rivers towards the Konkan Ghats. It is also found in Nilatwar near Kaladghi, bank of the Gatpraba River, Bihar, Central Provinces and Western Peninsula [4]. Treatment of P. lawii together with powdered sugar candy is taken orally for 7 days in stomach and other cancers barring brain and lung cancer [5]. The aerial parts of $P$. lawii was tested for hepatoprotective activity against $\mathrm{CCl}_{4}$ in rats and it has shown significant activity, lowering the serum enzymes like SGOT and SGPT in rats intoxicated with $\mathrm{CCl}_{4}[6]$. Diuretic activity in rats and hypothermic effect in mice of $P$. lawii has been reported earlier [7]. The present study is to investigate and evaluate the pharmacological basis for the use of $P$. lawii in the folk medicine for the treatment of pain.

\section{MATERIALS AND METHODS}

\section{Plant Material}

The aerial parts of the plant Phyllanthus lawii was collected from Mangalore of Karnataka, India in December 2007. The plant material was identified and authenticated by

*Address Correspondence to this author at the Manipal College of Pharmaceutical Sciences, Manipal University, Manipal-576104, India;

Tel: +91 0820 2571201; Fax: +910820 2203992;

E-mail: cksbhat@yahoo.co.in
Dr. Gopalkrishna Bhat, Department of Botany, Poorna Prajna College, Udupi, Karnataka, India. A voucher specimen has been kept in the Herbarium of the college. A voucher specimen $\mathrm{CH} / \mathrm{NGSM}$-IF 47 is deposited in the Herbarium of NGSM Institute of Pharmaceutical Sciences.

\section{Extraction}

The plant material was dried in shady place and then powdered with a mechanical grinder and stored in airtight container. About $500 \mathrm{~g}$ of the powder was extracted using soxhlet apparatus for $12 \mathrm{~h}$ using $5.0 \mathrm{~L}$ of methanol as solvent. The extract was made free from solvent by keeping it on water bath at $50-60^{\circ} \mathrm{C}$ for about $6 \mathrm{~h}$ and gave a yield of $9.25 \%$.

\section{Animals}

Male Swiss albino mice weighing 20-25 g were obtained from an animal colony of NGSM Institute of Pharmaceutical Sciences, Paneer, Deralakatte, Mangalore, India. They were kept in departmental animal house in polypropylene cages in an air-conditioned area at $25 \pm 2^{\circ} \mathrm{C}$ with $10: 14 \mathrm{~h}$ light and dark cycle and maintained on Amrut brand balanced animal feed and water ad libitum. The experimental protocols were approved by the Animal Ethical Committee of Nitte University.

\section{Chemicals}

The drugs and chemicals used were Aspirin (Research Lab, Mumbai), gum acacia (SD fine chemicals Limited, Mumbai), pentazocin (Pure Pharma Ltd, Mumbai) and Methanol (BDH, Mumbai).

\section{Toxicity Assay}

The $\mathrm{LD}_{50}$ was determined using the graphical method [8] in mice. Briefly, geometric doses of the extract (100-2,000 $\mathrm{mg} / \mathrm{kg}$ ) were administered i.p. to 10 groups of mice each 
consisting of six animals. Control group received normal saline $(5 \mathrm{~mL} / \mathrm{kg}$ i.p.). Signs of toxicity and mortality within 24-72 h were noted. Confirmatory test was carried out and the $\mathrm{LD}_{50}$ was calculated from the graph of percent mortality against profit log dose of the extract.

\section{Analgesic Activity}

\section{Hot plate Method (Thermal Stimulation)}

In the hot plate method, albino mice (20-25 g) were divided into 3 groups each consisting of six animals. One group served as negative control (received 5\% gum acacia $5 \mathrm{~mL} / \mathrm{kg}$. Second group served a positive control (pentazocin $5 \mathrm{mg} / \mathrm{kg}$ ). While the third received MEPL (200 mg/kg, p.o.). The basal reaction time was noted 1,2 , and $3 \mathrm{~h}$ after the treatments [9].

\section{Acetic acid Induced Writhing Test (Chemical Stimulation)}

In acetic acid induced writhing model [10], albino mice (20-25 g) were divided into three groups each consisting of six animals. One group served as negative control (received $2 \%$ gum acacia $\mathrm{mL} / \mathrm{kg}$ ), Second group served as positive control (received aspirin $100 \mathrm{mg} / \mathrm{kg}$ ), while third group received MEPL (200 mg/kg) orally. The writhing movements were observed and counted for $30 \mathrm{~min}$ after acetic acid administration.

\section{Statistical Analysis}

Statistical analysis of data was presented using Student's t test [11].

\section{RESULTS AND DISCUSSION}

The MEPL treatments (100-2,000 mg/kg) did not cause significant changes in behavior or weight of mice. The extract is considered to be of low toxicity according to the reference of Lorke [12]. The results of hot plate test indicated a significant increase in reaction time at 2 and $3 \mathrm{~h}$ with 200 $\mathrm{mg} / \mathrm{kg}$ of MEPL whereas reference drug pentazocin significantly increased the reaction time at 1 to $2 \mathrm{~h}$ (Table $\mathbf{1}$ ). In acetic acid induced writhing test, MEPL (200 mg/kg) reduced writhing count significantly, inhibiting pain by $69.00 \%$ compared to control (Table 2).

Pain and inflammation are associated with pathology of various clinical conditions like arthritis, cancer, and vascular diseases [13]. In various traditional medicinal systems a number of natural products are used to relieve the symptoms of pain. The MEPL exhibited a significant analgesic activity in different animal models of pain. The hot plate method has been found to be suitable for evaluation of centrally acting analgesics [14]. The nociceptors seem to be sensitized by sensory nerves. The involvement of endogenous substances such as PGs may be minimized by this model. In centrally acting analgesic methods, the extract of $200 \mathrm{mg} / \mathrm{kg}$ dose was found to be significantly effective. Acetic acid induced abdominal contraction method has been used to evaluate peripherally acting analgesics. In acetic acid induced method pain is generated indirectly via endogenous mediators like prostaglandin, which stimulates peripheral nociceptive neurons. These neuronal fibers are sensitive to both narcotics and non steroidal anti-inflammatory drugs [15]. MEPL inhibited the acetic acid induced pain with potency compared to the aspirin. The standard drug aspirin produced inhibition of writhing movement inhibiting peripheral pain induced by direct action of acetic acid. MEPL is dominated by pentacyclic triterpenoids [16]. Pentacyclic triterpenoids have potent analgesic activity [17]. Triterpenoids are reported to be inhibitors of $\mathrm{NF}_{-} \mathrm{B}$ signaling [18] just like aspirin and other NSAIDS [19]. These evidences reveal that pentacyclic triterpenoids may be responsible for the analgesic activity of MEPL.

\section{ABBREVIATIONS}

Table 1. Effect of the Methanol Extract of Phyllanthus lawii (MEPL) on Thermal Stimulus Induced Pain (Hot Plate Test) in Mice

\begin{tabular}{|c|c|c|c|c|c|}
\hline \multirow{2}{*}{ Treatment } & \multirow{2}{*}{$\begin{array}{c}\text { Dose } \\
(\mathrm{mg} / \mathrm{kg})\end{array}$} & \multicolumn{4}{|c|}{ Reaction Time (Seconds) } \\
\hline & & $\mathbf{0}$ & $1 \mathrm{~h}$ & $2 \mathrm{~h}$ & $3 \mathrm{~h}$ \\
\hline Control (5\% gum acacia) & 5 & $4.45 \pm 0.11$ & $5.11 \pm 0.12$ & $5.12 \pm 0.15$ & $4.55 \pm 0.05$ \\
\hline MEPL & 200 & $4.36 \pm 0.64$ & $6.47 \pm 0.46^{*}$ & $9.47 \pm 0.45^{* *}$ & $7.89 \pm 0.12 * *$ \\
\hline
\end{tabular}

$* * \mathrm{P}<0.001 ; * \mathrm{P}<0.05$ when compared to control. Values are expressed as mean $\pm \mathrm{SEM}$.

Table 2. Effect of the Methanol Extract of Phyllanthus lawii (MEPL) on Acetic acid Induced Writhing in Mice

\begin{tabular}{|l|c|c|c|}
\hline \multicolumn{1}{|c|}{ Treatment } & Dose & $\begin{array}{c}\text { Number of Writhes } \\
\text { (Per 30 Min) }\end{array}$ & Percentage Inhibition of Writhes \\
\hline \hline Control (5\% gum acacia) & $5 \mathrm{~mL} / \mathrm{kg}$ & $89 \pm 0.22$ & $24 \pm 0.45^{* *}$ \\
\hline Aspirin & $50 \mathrm{mg} / \mathrm{kg}$ & $31 \pm 0.24 * *$ & 74.00 \\
\hline MEPL & $200 \mathrm{mg} / \mathrm{kg}$ & 69.00 \\
\hline
\end{tabular}

** $\mathrm{P}<0.001$ when compared to control. Values are expressed as mean $\pm \mathrm{SEM}$. 
MEPL $=$ Methanol extract of Phyllanthus lawii

NGSM = Nitte Gulabi Shetty Memorial

SEM $=$ Standard Error Mean

NSAIDS $=$ Nonsteroidal antiinflammatory drugs

\section{REFERENCES}

[1] Sayyada, K.; Vartika, R.; Ajay, K.R.; Shanta, M. Comparative pharmacognostic studies of three Phyllanthus species. J. Ethnopharmacol., 2006, 104, 79-86.

[2] João, B.C.; Adair, R.S.; Valdir, C. F.; Rosendo, A. Y. A review of the plants of the genus Phyllanthus: Their chemistry, pharmacology, and therapeutic potential. Med. Res. Rev., 1998, 18, 225-258.

[3] Srirama, R.; Santilkumar, U.; Sreejayan, N.; Ravikanth, G.; Gurumurthy, B.R.; Shivanna, M.B.; Sanjappa, M.; Ganeshaiah, K.N.; Uma Shaanker, R. Assessing species admixtures in raw drug trade of Phyllanthus, a hepatoprotective plant using molecular tools. $J$. Ethnopharmacol., 2010, 130, 208-215.

[4] Cooke, T. The Flora of the Presidency of Bombay, 1906, Vol III, 82.

[5] Prusti, A.R.; Behera, K.K. Ethno-Medico Botanical study of Sundargarh District, Orissa, India. Ethnobot. Leaflet, 2007, 11, 148-163.

[6] Chandrashekar, K.S.; Prasanna, K.S. Hepatoprotective activity of Phyllanthus lawii against carbon tetrachloride induced Hepatic damage in rats. Intl. J. Pharm. Biol. Arch., 2010, 1, 187-188.

[7] Dhawan, B.N.; Patnik, G.K.; Rastogi, R.P.; Singh, K.K.; Tandonn, J.S. Screening of Indian plants for biological activity: Part VI. Ind. J. Exp. Biol., 1977, 15, 208-219.
[8] Litchfield, J.T.; Wilcoxon, F. A simplified method of evaluating dose-effect experiments. J. Pharmacol. Exp. Ther., 1949, 96, 99133.

[9] Turner, R.A. Screening methods in Pharmacology. New York, Academic press, 1971, 100-113.

[10] Koster, R. Acetic acid for analgesic screening. Fed. Proc., 1958, $18,412$.

[11] Snedecor, G.W.; Cochran, W.G. Statistical methods. New Delhi, IBH Publishing company. 1979, 147.

[12] Lorke, D. A new approach to practical acute toxicity testing. Arch. Toxicol. 1983, 54, 275-287.

[13] Weitzmann, S.A.; Gordan, L.I. Inflammation and Cancer, role of phagocyte generated oxidants in carcenogenisis. Blood, 1990, 76(4), 655-663.

[14] Woolfe, G.; MacDonald, A.D. The evaluation of analgesic action of Pethidine Hydrochloride. J. Pharmacol. Exp. Ther., 1969, 166, 96-103.

[15] Colier, H.O.; Dinneen, L.C.; Johnson, C.A.; Schneider, C. The abdominal constriction response and its suppression by analgesic drugs in mouse. Pharmacology, 1968, 32, 295-310.

[16] Chandrashekar, K.S. Thesis, Rajiv Gandhi University of Health Sciences, 2005.

[17] Biswas, M.; Biswas, K.; Ghosh, A.K.; Haldar, P.K. A Pentacyclic triterpenoid possessing analgesic activity for the fruit of Dregea volubilis. Pharmacogn. Magaz., 2009, 5(19), 90-92.

[18] Salminen, A.; Lehtonen, M.; Suuronen, T.; Kaarniranta, K.; Huuskonen, J. Terpenoids: natural inhibitors of $\mathrm{NF}_{-\mathrm{K}} \mathrm{B}$ and signaling with anti-inflammatory and anticancer potential. CMLS, 2008, 65, 2979.

[19] Muller, D.N.; Heissmeyer, V.; Dechend, R.; Hamich, F.; Park, J.K.; Fiebler, A.; Shagdarsuren, E.; Theuer, J.; Elger, M.; Pilz, B. Aspirin inhibit $\mathrm{NF}_{-} \mathrm{B}$ and protects from angiotensin II- induced organ damage. FASEBJ., 2001, 15, 100, 347.

Received: January 11, 2011

Revised: February 18, 2011

Accepted: February 21, 2011

(C) Chandrashekar et al.; Licensee Bentham Open.

This is an open access article licensed under the terms of the Creative Commons Attribution Non-Commercial License (http://creativecommons.org/ licenses/ by-nc/3.0/) which permits unrestricted, non-commercial use, distribution and reproduction in any medium, provided the work is properly cited. 